\title{
VITAROVAT
}

\section{A fizikai talajféleség hatásának szimulációja a talaj felszíni nedvesség-változására}

\author{
${ }^{1}$ ÁCS FERENC és ${ }^{2}$ LÖKE ZSUZSANNA
}

${ }^{1}$ ELTE, Meteorológiai Tanszék, Budapest és ${ }^{2}$ Veszprémi Egyetem Georgikon Mezőgazdaságtudományi Kar, Vízgazdálkodási, Meliorációs és Agrometeorológia Tanszék, Keszthely

\section{Bevezetés}

A talaj-növény-légkör rendszer állapotát és átviteli folyamatait leíró biofizikai modellek egyik alapvető problémája az, hogy nagymértékben érzékenyek olyan paraméterekre is, melyek értéke nem ismert vagy nagytérségi mérésük még nem megoldott. Az ilyen paraméterek csoportjába tartozik például a talaj fizikai félesége és a gyökérsürüség. A talaj fizikai félesége mindenféleképpen több figyelmet érdemel talajtani, meteorológiai és hidrológiai vonatkozásban is. A több tíz vagy száz $\mathrm{km}^{2}$ nagyságú terület fizikai talajfélesége több okból kifolyólag is bizonytalan adatnak tekinthető. Ennek oka elsősorban a fizikai talajféleség nagymértékü térbeli változékonysága, aminek következtében homogén terület kijelölése nem egyszerü feladat. Másodsorban pedig talajtérképeink csak a domináns fizikai talajféleséget adják meg, azaz nincs információnk a fizikai talajféleség területi eloszlásáról a talaj felszíni müvelt rétegére vonatkozóan. A magyarországi térképek (VÁRALLYAY et al., 1980) az esetek többségében a felszíni rétegre vonatkozóan adnak információt. Ugyanezen térképek kevesebb információt szolgáltatnak a fizikai talajféleség mélység szerinti eloszlásáról.

Mindezek alapján az volt az alapvető célunk, hogy számszerüsítsük a biofizikai modellek érzékenységét a fizikai talajféleség különbözőségére. Az eddigi vizsgálatok eredményei alapján az érzékenység erősnek mutatkozott (PITMAN, 1994), és ez legjobban a klimatológiai skálán jut kifejezésre (IRANNEJAD \& SHAO, 1998). Az érzékenységet rövidebb, néhány napos időskálán MIHAILOVIC és munkatársai (1992) mutatták ki. Az eddigi tanulmányok föképpen a felszíni réteg fizikai talajféleség változásainak hatásait jellemezték. A jelen tanulmány célja a korábbiakban nem szereplö, vagy csak részlegesen érintett érzékenységi vizsgálatok végzése. Numerikus vizsgálataink során a párolgás 
és a felszíni nedvességtartalom érzékenységét elemeztük rövid időskálán (6 napos időszak 1992. április 28-tól május 3-ig) homogén növénymentes (néhány $\mathrm{m}^{2}$-es) talajfelszín felett

a) a felszíni- és

b) a felszín alatti fizikai talajféleség változásokra.

Célunk elsősorban az volt, hogy e két változásra való érzékenységet számszerüsítsük és vessük össze.

\section{Anyag és módszer}

\section{A modell bemutatása}

A vizsgálatokat a SURFMOD biofizikai modellcsalád (Ács et al., 2000a) PMSURF modellváltozatával (ÁCS \& HANTEL, 1999) végeztük. A modellt egy egyrétegü növényállomány és többrétegü talajmodell alkotja. A felszín három felszíntípusra tagolható (1. ábra): csupasz talajra; száraz (azaz vízréteg nélküli), valamint nedves (azaz vízzel borított) növényállományra. Elörejelzett változók:

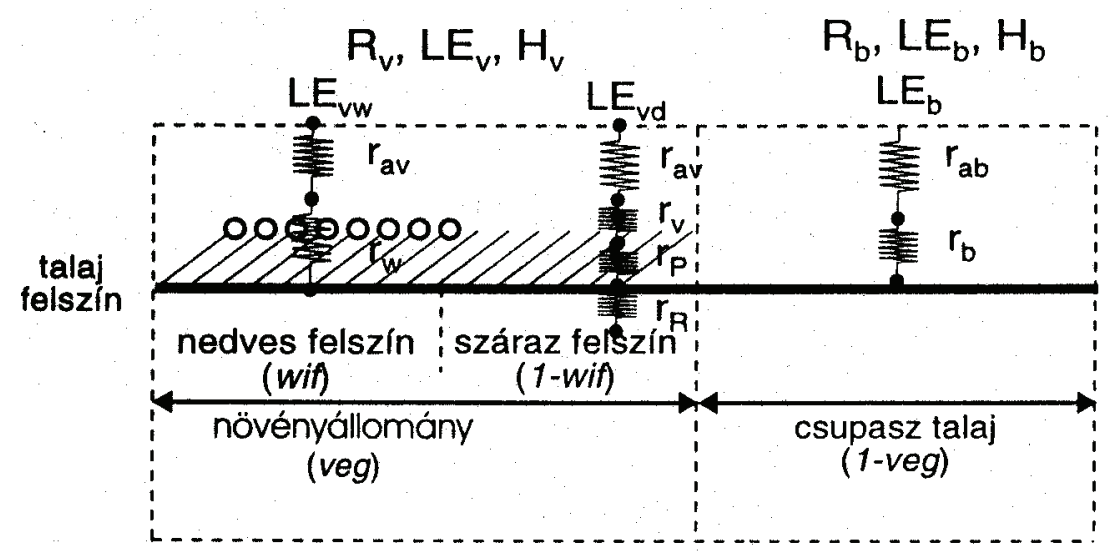

1. ábra

A PROGSURF modell ellenállásrendszere. Jelmagyarázat: $R_{v}, H_{v}, L_{v}=$ sugárzási egyenleg, szenzibilis hőáram és látens hőáram az állomány felett; $\mathrm{LE}_{\mathrm{vw}}$ és $\mathrm{LE}_{\mathrm{vd}}=$ látens hőáram a nedves és a száraz növényállomány felett; $\mathrm{R}_{\mathrm{b}}, \mathrm{H}_{\mathrm{b}}, \mathrm{LE}_{\mathrm{b}}=$ sugárzási egyenleg, szenzibilis hőáram és látens hőáram a csupasz talaj felett; $r_{\mathrm{av}}$ és $r_{\mathrm{ab}}=$ aerodinamikai ellenállás a vízgőz átvitelével szemben az állomány és a csupasz talaj felett; $r_{w}, r_{v}$ és $r_{b}=$ a nedves és a száraz növényállomány, valamint a csupasz talajfelszín felszíni ellenállása a vízgőz átvitelével szemben; $\mathrm{r}_{\mathrm{P}}=$ a növényi szár ellenállása a víz átvitelével szemben; $\mathrm{r}_{\mathrm{R}}=$ a gyökérzet ellenállása a víz átvitelével szemben; wif = a nedves felszínü növényállomány relatív nagysága; veg = a száraz felszínű növényállomány relatív nagysága 
a növényállomány felszíni víztározása és a talajrétegek nedvességtartalma. A modell a talajnedvesség változását a Richards-egyenlet (RICHARDS, 1931), míg a légköri turbulens áramokat a Penman-Monteith koncepció alapján értékeli. A talaj-növény-légkör rendszer átviteli folyamatait az 1. ábrán látható ellenállásrendszerrel írtuk le (ÁCS \& HANTEL, 1999; ÁCS et al., 2000b). A biofizikai modellezésben az ellenállás-koncepciót az elektromosságtanban használt Ohm-törvény analógiájára vezették be (MÉSZÁros et al., 2001). A növények vízellátottságát az állomány átlagos levél-vízpotenciáljának számításán keresztül jellemeztük. A talaj nedvességpotenciáljának, vízvezető képességének és nedvességtartalmának kapcsolatát az ismert Clapp és Hornberger-féle képletek alapján értékeltük (CLAPP \& HORNBERGER, 1978). A modell részletes ismertetése a hazai szakirodalomban is megtalálható (ÁCS, 1998; ÁCS \& HANTEL, 1999; ÁCS et al., 2000a). A talajmodell-egység bemutatása a nemzetközi PILPS (Project for Intercomparison of Land-Surface Parameterization Schemes) projekt keretében is megtörtént (ÁCS \& HANTEL, 1998). A biofizikai modellek közül a SURFMOD biofizikai modellcsalád is nagy tér- (több $\mathrm{km}^{2}$-es terület) és rövid idöskálán (néhány perctől egy órás időléptékig) müködik (SHUTTLEWORTH, 1988).

Csupasz talajfelszín esetén a meghatározó egyenletek a következők:

$$
\begin{gathered}
\varsigma_{w} \cdot D_{1} \cdot \frac{\partial \theta_{1}}{\partial t}=P_{i}-E_{b}-Q_{r s}-Q_{1} \\
S_{w} \cdot D_{2} \cdot \frac{\partial \theta_{2}}{\partial t}=Q_{1}-Q_{2} \\
\varsigma_{w} \cdot D_{3} \cdot \frac{\partial \theta_{3}}{\partial t}=Q_{2}-Q_{3}
\end{gathered}
$$

ahol: $\varsigma_{\mathrm{w}}$ a víz sürüsége, $\mathrm{D}_{\mathrm{i}}$ az i-edik talajréteg vastagsága, $\theta_{\mathrm{i}}$ az i-edik talajréteg nedvességtartalma, $P_{i}$ az infiltráció intenzitása, $E_{b}$ a párolgás intenzitása, $Q_{r s}$ a felszíni lefolyás intenzitása, $\mathrm{Q}_{1}$ és $\mathrm{Q}_{2}$ az első és a második, valamint a második és a harmadik talajréteg közötti talajnedvesség diffúziós árama, $\mathrm{Q}_{3}$ a harmadik talajrétegböl történő gravitációs lefolyás oldalirányú komponense. Ezen összetevő csak akkor különbözik a nullától, ha a felszín lejt. A lefelé irányuló áramok pozitívak, míg a felfelé irányuló áramok negatívak. A két oldalirányú áram $\left(\mathrm{Q}_{\mathrm{rs}}\right.$ és a $\left.\mathrm{Q}_{3}\right)$ - ha létezik - mindig pozitív. $\mathrm{A}$ $\mathrm{Q}_{1}$ és $\mathrm{Q}_{2}$ talajnedvesség-áramokat Darcy törvénye alapján parametrizáltuk (Ács et al., 2000b):

$$
\begin{array}{r}
Q_{1}=\varsigma_{w} \cdot K_{e f, i} \cdot\left\{2 \cdot \frac{\Psi_{1}-\Psi_{i+1}}{D_{i}+D_{i+1}}+1\right\}, \\
K_{e f, i}=\frac{D_{i} \cdot K_{i}+D_{i+1} \cdot K_{i+1}}{D_{i}+D_{i+1}}
\end{array}
$$




$$
\begin{gathered}
\mathrm{K}_{\mathrm{i}}=\mathrm{K}_{\mathrm{si}} \cdot\left(\frac{\theta_{\mathrm{i}}}{\theta_{\mathrm{si}}}\right)^{2 \mathrm{~b}_{\mathrm{i}}+3} \\
\Psi_{\mathrm{i}}=\Psi_{\mathrm{si}} \cdot\left(\frac{\theta_{\mathrm{i}}}{\theta_{\mathrm{si}}}\right)^{-\mathrm{b}_{\mathrm{i}}}
\end{gathered}
$$

ahol: $\theta_{\mathrm{si}}, \mathrm{K}_{\mathrm{si}}$ és $\Psi_{\mathrm{si}}$ az i-edik réteg telítési nedvességtartalma, vízvezető képessége és talajnedvesség-potenciálja. $\mathrm{b}_{\mathrm{i}}$ az i-edik réteg Clapp-Hornberger-féle állandója. Az állandók a talaj fizikai féleségétől függnek (például: COSBY et al., 1984 vagy CLAPP \& Hornberger, 1978). Az $\mathrm{E}_{\mathrm{b}}$-párolgást a Penman-Monteith-féle képlet alapján számítottuk (MONTEITH, 1965):

$$
L \cdot E_{b}=\frac{\Delta \cdot\left(R_{n}-G\right)+\varsigma \cdot c_{p} \cdot \delta e / r_{a}}{\Delta+\gamma \cdot\left(1+r_{b} / r_{a}\right)}
$$

ahol: L a látens hőáram, $\Delta$ a telvtısi vízgőznyomás hőmérséklettel szembeni változása, $R_{n}$ a csupasz talajfelszín sugárzási egyenlege, $G$ a talajhőáram a felszínen, $\varsigma$ a levegő sürüsége, $\mathrm{c}_{\mathrm{p}}$ a levegö állandó nyomáson vett fajhője, $\delta \mathrm{e}$ a vvzgvzhiány, $\mathrm{r}_{\mathrm{a}}$ a felszín és a referenciaszint közötti aerodinamikai ellenállás, $\gamma$ a pszichrometrikus állandó és $r_{b} a$ csupasz talajfelszín felszíni ellenállása a párolgással szemben. $\mathrm{A} \mathrm{Q}_{\mathrm{rs}}$ és $\mathrm{Q}_{3}$ tagok nem fontosak a mi esetünkben, ezért parametrizálásukat nem mutatjuk be.

\section{Numerikus vizsgálatok}

Numerikus kísérleteinkben semleges rétegződésű a légkör, azaz az aerodinamikai ellenállás a szélsebesség függvényében változik. A modell futtatásához szükséges adatsorok: a légköri határfeltételek és a talajadatok. A talajadatokat a talajnedvesség kezdeti értékei és a talajok vízgazdálkodási tulajdonságai alkotják. Kísérleteink során a légköri határfeltételeket állandónak, míg a talajadatokat változónak vettük. Az érzékenységi vizsgálatokat a talajnedvesség különböző feltételeire és a talaj különböző vízgazdálkodási tulajdonságaira vonatkozóan végeztük el.

\section{Az érzékenységi vizsgálatok esetei}

Az érzékenységi vizsgálatok eseteit az 1. táblázat szemlélteti. A kezdeti talajnedvességre vonatkozóan megkülönböztettünk „,száraz” és „,nedves” esetet. A fizikai talajféleség kombinációkat „változó felszíni” és ,állandó felszín alatti”, valamint ,állandó felszíni” és ,változó felszín alatti” esetekkel vettük figyelembe. A ,változó felszíni” és ,állandó felszín alatti” fizikai talajféleség kombinációt a következőképpen definiáltuk: A felszíni $\mathrm{D}_{1}$ vastagságú réteg fizikai talajfélesége homok vagy agyag (maximális eltérés a talaj fizikai féleségek között), 
AGROKÉMIA ÉS TALAJTAN Tom. 50. (2001) No. 3-4.

\section{1. táblázat}

Az érzékenységi vizsgálatok lehetséges esetei a talajnedvesség és a talaj fizikai féleségének különböző kombinációira

\begin{tabular}{|c|c|c|}
\hline $\begin{array}{c}\text { Nedvesség } \\
{\left[\mathbf{m}^{3} \mathbf{m}^{-3}\right]}\end{array}$ & \multicolumn{2}{|c|}{ Fizikai talajféleség } \\
\hline \multirow{2}{*}{$\boldsymbol{S z a ́ r a z}$} & VÁLTOZÓ FELSZÍNI & ÁLLANDÓ FELSZÍN ALATTI \\
\cline { 2 - 3 }$\theta_{1}=0,10$ & $\mathrm{D}_{1}=$ homok & $\mathrm{D}_{1}=$ agyag \\
$\theta_{2}=0,08$ & Ás $\mathrm{D}_{3}=$ vályog \\
\cline { 2 - 3 }$\theta_{3}=0,06$ & $\mathrm{D}_{1}=$ homokos agyag & $\begin{array}{c}\mathrm{D}_{2} \text { és } \mathrm{D}_{3}=\text { homok } \\
\mathrm{D}_{2} \text { és } \mathrm{D}_{3}=\text { agyag }\end{array}$ \\
\cline { 2 - 3 } Nedves & VÁLTOZÓ FELSZÍNI & ÁLLANDÓ FELSZÍ́N ALATTI \\
\cline { 2 - 3 }$\theta_{1}=0,18$ & $\mathrm{D}_{1}=$ homok & $\mathrm{D}_{2}$ és $\mathrm{D}_{3}=$ vályog \\
$\theta_{2}=0,14$ & $\mathrm{D}_{1}=$ agyag & VÁLTOZÓ FELSZÍ́N ALATTI \\
\cline { 2 - 3 }$\theta_{3}=0,13$ & ÁLLANDÓ FELSZÍNI & $\mathrm{D}_{2}$ és $\mathrm{D}_{3}=$ homok \\
\cline { 2 - 3 } & $\mathrm{D}_{1}=$ homokos agyag & $\mathrm{D}_{2}$ és $\mathrm{D}_{3}=$ agyag \\
\hline
\end{tabular}

míg a felszín alatti $D_{2}$ és $D_{3}$ vastagságú rétegek fizikai talajfélesége vályog. Hasonlóképpen definiáltuk az „állandó felszíni” és „változó felszín alatti” eset fizikai talajféleség kombinációját: a felszíni $\mathrm{D}_{1}$-es réteg homokos agyag, míg a felszín alatti $\mathrm{D}_{2}$-es és $\mathrm{D}_{3}$-as rétegek homok vagy agyag.

A fentiek alapján a „száraz” esetben a következő fizikai talajféleség kombinációkra végeztünk modellfuttatásokat:

1. $\mathrm{D}_{1}=$ homok, $\mathrm{D}_{2}=$ vályog és $\mathrm{D}_{3}=$ vályog,

2. $\mathrm{D}_{1}=$ agyag, $\mathrm{D}_{2}=$ vályog és $\mathrm{D}_{3}=$ vályog,

3. $\mathrm{D}_{1}=$ homokos agyag, $\mathrm{D}_{2}=$ homok és $\mathrm{D}_{3}=$ homok, és

4. $\mathrm{D}_{1}=$ homokos agyag, $\mathrm{D}_{2}=$ agyag és $\mathrm{D}_{3}=$ agyag.

Az 1-es és 2-es futtatás eredményeinek az összehasonlításával a felszíni fizikai talajféleség-eltérések, míg a 3-as és 4-es futtatás eredményeinek összehasonlításával a felszín alatti fizikai talajféleség-eltérések hatásait vizsgálhattuk. Ugyanezen futtatásokat a nedves esetre vonatkozóan is elvégeztük. A talajrétegek vastagságai: $\mathrm{D}_{1}=0,1 \mathrm{~m}, \mathrm{D}_{2}=0,4 \mathrm{~m}$ és $\mathrm{D}_{3}=0,5 \mathrm{~m}$. Numerikus vizsgálatainkban a csupasz talajfelszínt homogénnek tekintettük.

\section{Légköri határfeltételek}

A légköri határfeltételeket a braunschweigi szinoptikus állomás hatnapos mérési adatsora biztosította, mely negyedóránként tartalmazta a globálsugárzás, a légköri visszasugárzás, a léghőmérséklet, a légnedvesség, a szélsebesség és a 
csapadék mért értékeit. Az adatsort azért választottuk, mert rövid időszakban változékony időjárást ír le. Így a globálsugárzás nagymértékủ változékonysága mellett háromszor is van csapadék.

\section{Talajadatok}

A talajok kezdeti nedvességtartalom értékeit az 1. táblázat, a vízgazdálkodási tulajdonságok értékeit a 2. táblázat tartalmazza. A vízgazdálkodási tulajdonságokat leíró értékeket CLAPP és HORNBERGER (1978) munkájából vettük.

\section{2. táblázat}

Egyes fizikai talajféleségek vízgazdálkodási tulajdonságai

\begin{tabular}{|l|c|c|c|c|}
\hline \multirow{2}{*}{$\begin{array}{c}\text { Fizikai } \\
\text { talajféleség }\end{array}$} & \multicolumn{4}{|c|}{ Vízgazdálkodási tulajdonság } \\
\cline { 2 - 5 } & $\Psi_{\mathrm{s}}[\mathbf{m}]$ & $\mathbf{K}_{\mathrm{s}}[\mathbf{m} / \mathbf{s}]$ & $\mathbf{b}$ & $\boldsymbol{\theta}_{\mathbf{s}}\left[\mathbf{m}^{\mathbf{3}} / \mathbf{m}^{\mathbf{3}}\right]$ \\
\hline Homok & $-0,121$ & $176 \cdot 10^{-6}$ & 4,05 & 0,395 \\
Homokos agyag & $-0,153$ & $2,2 \cdot 10^{-6}$ & 10,4 & 0,426 \\
Agyag & $-0,405$ & $1,3 \cdot 10^{-6}$ & 11,4 & 0,482 \\
Vályog & $-0,478$ & $7 \cdot 10^{-6}$ & 5,39 & 0,451 \\
\hline
\end{tabular}

\section{Vizsgálati eredmények}

Mind a „száraz”, mind a „nedves” esetben azt tapasztaltuk, hogy a párolgás és a felszíni nedvességtartalom érzékeny a fizikai talajféleség-változásokra. A következőkben csak a „száraz” esetre vonatkozó eredményeinket mutatjuk be.

\section{Felszini fizikai talajféleség-eltérések}

Száraz esetben a felszíni fizikai talajféleség-eltérésekre való érzékenységet a 2. ábra szemlélteti. A 2.A. ábra a felszíni réteg nedvességtartalom-, míg a 2.B. ábra a párolgás érzékenységét mutatja. A felszíni agyagréteg nedvességtartalma $\left(\theta_{\text {agy }}{ }^{\text {vá }}\right)$ számottevően nagyobb a felszíni homokréteg nedvességtartalmánál $\left(\theta_{\text {ho }}{ }^{\text {vá }}\right)$. Jelölésünk szerint az alsó index a felszíni, míg a felső index a két felszín alatti réteg fizikai talajféleségét mutatja. A kezdeti időszakban a $\theta_{\text {agy }}^{\text {vá fokoza- }}$

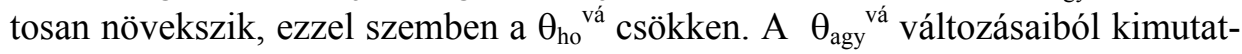
ható, hogy a felszíni agyagréteg szívóhatást fejt ki az alatta levő vályogra, mert szárazabb, annak ellenére, hogy nedvességtartalma nagyobb, mint az alatta levő vályogé (3. ábra).

Ezt egy konkrét példán illusztráljuk: A szimuláció első napján 12 óra 15 perckor $\theta_{\mathrm{agy}}=0,105 \mathrm{~m}^{3} / \mathrm{m}^{3}, \theta^{\text {vá }}=0,0766 \mathrm{~m}^{3} / \mathrm{m}^{3}$. A vízgazdálkodási állandók a 
A.
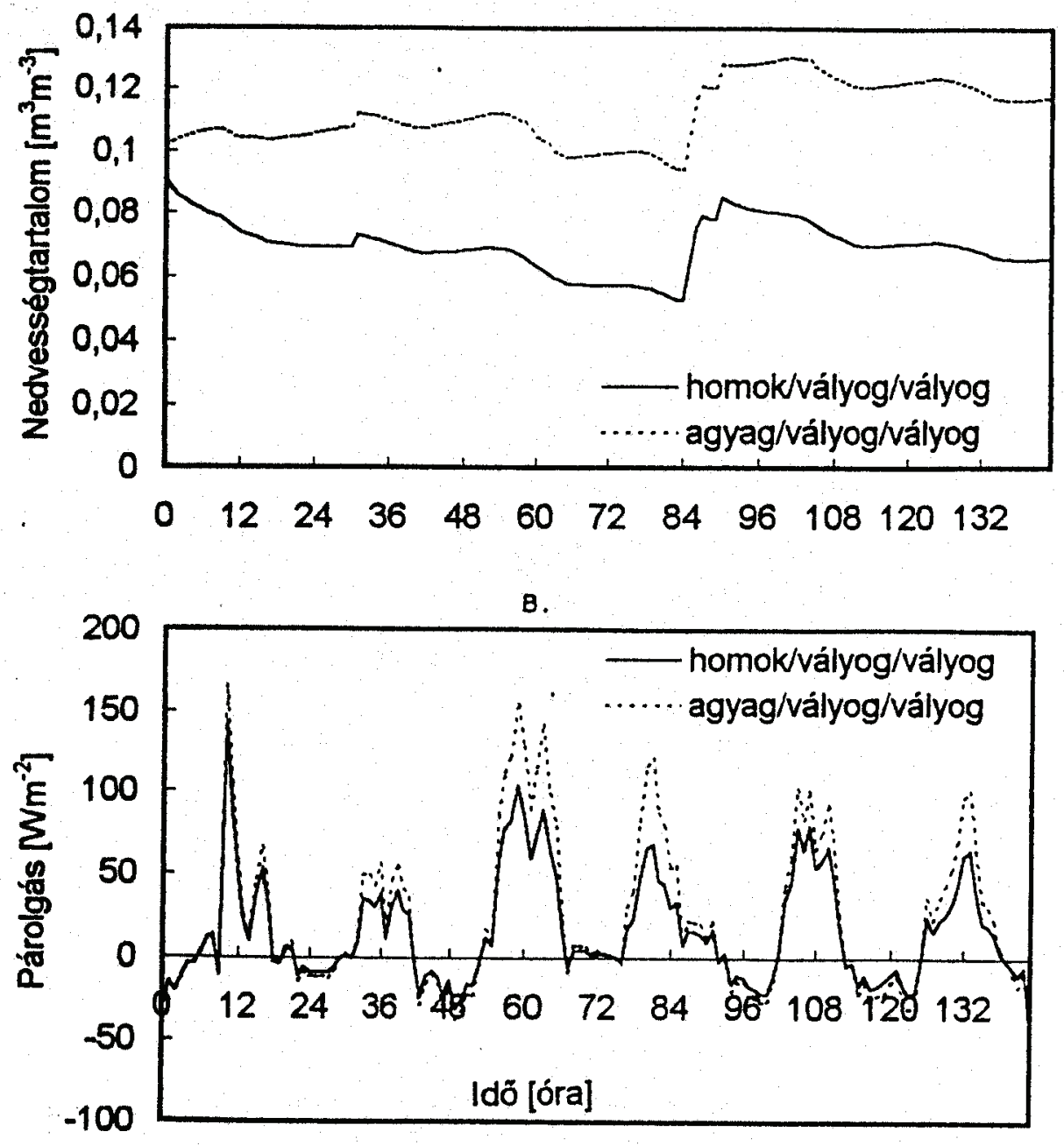

2 ábra

A felszíni agyag- (szaggatott vonal) és homokréteg (telt vonal) nedvességtartalmának (A), illetve párolgásának (B) időbeni változása az 1992. április 28. és május 3. közötti időszakban. A felszín alatti két réteg textúrája: vályog

2. táblázatban adottak, így $\Psi_{\text {agy }}=-1421,1 \cdot 10^{4} \mathrm{~m}$, míg $\Psi^{\mathrm{vá}}=-6752,2 \mathrm{~m}$ nedvességpotenciál, azaz láthatjuk, hogy a $0,105 \mathrm{~m}^{3} / \mathrm{m}^{3}$ nedvességtartalmú felszíni agyagos réteg szárazabb, mint a $0,0766 \mathrm{~m}^{3} / \mathrm{m}^{3}$ nedvességtartalmú felszín alatti vályog. E nedvességpotenciál-gradienshez tartozó felfelé irányuló $\mathrm{Q}_{1}$ talajvízáram intenzitás értéke $-0,11 \cdot 10^{-7} \mathrm{~m} / \mathrm{s}$, ami részlegesen hozzájárul a $0,31 \cdot 10^{-7} \mathrm{~m} / \mathrm{s}$ 


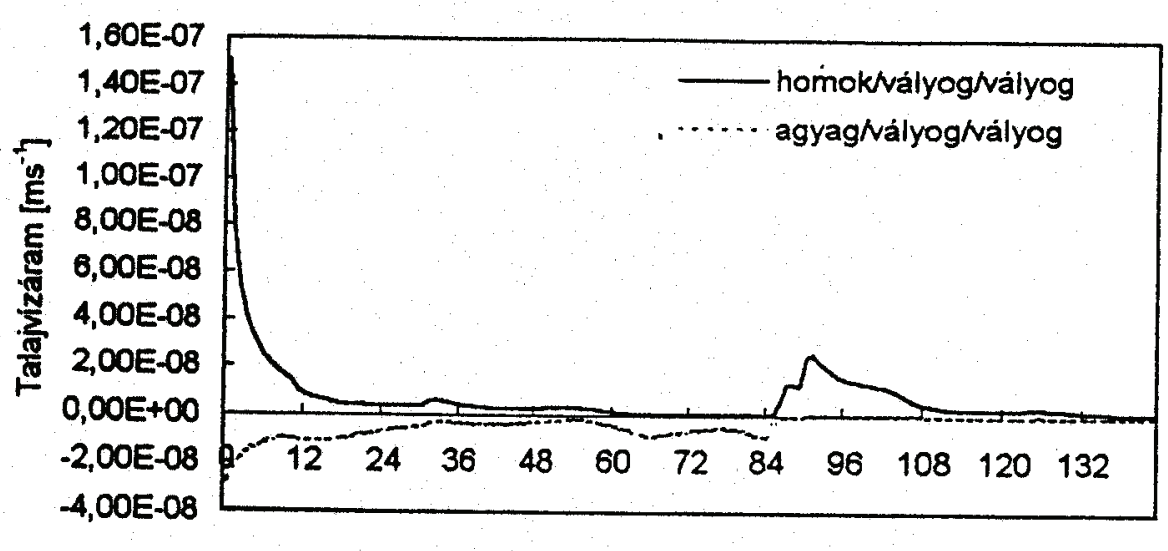

Idō [óra]

3. ábra

A talajvízáram időbeni változása a felszíni agyag- (szaggatott vonal) és homokréteg (telt vonal) alján (10 cm-es mélységben) az 1992. április 28. és május 3. közötti időszakban. A felszín alatti két réteg textúrája vályog

párolgási fluxushoz. A $\theta_{\mathrm{ho}}{ }^{\text {vá }}$ csökkenő tendenciát mutat (eltekintve a csapadékhullás időszakaitól), habár vannak olyan időszakok is, amikor - mint az előbbi esetben - a homok nedvességtartalma kisebb, mint az alatta levő vályogé. Az

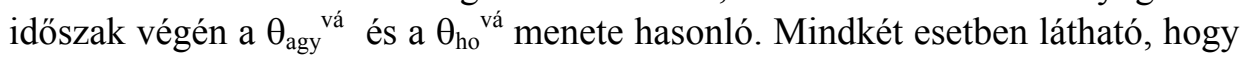
a csapadék növeli a talaj nedvességtartalom értékeit.

A nagyobb $\theta$-értékekhez nagyobb párolgási értékek tartoznak. Ez főleg a dél körüli órákban jut kifejezésre, amikor az agyagra $\mathrm{P}_{\text {agy }}$ vá és a homokra $\mathrm{P}_{\mathrm{ho}}$ vá vonatkozó párolgási értékek közötti eltérések elérhetik az $50 \mathrm{~W} / \mathrm{m}^{2}-\mathrm{t}$ is $(2 \mathrm{~B}$. ábra harmadik és negyedik nap). $\mathrm{A}\left[\left(\mathrm{P}_{\text {agy }}{ }^{\text {vá }}-\mathrm{P}_{\text {ho }}{ }^{\text {vá }}\right) / \mathrm{P}_{\text {ho }}{ }^{\text {vá }}\right]^{*} 100$ relatív eltérések elérhetik akár a $70 \%$-ot is (lásd a negyedik napot).

\section{Felszín alatti fizikai talajféleség-eltérések}

A felszín alatti fizikai talajféleség-eltérések hatásait a felszíni nedvességtartalom, valamint a párolgás változásaira a 4. ábra szemlélteti. A szimuláció első lépésében szembetünő a felszíni homokos agyagréteg nedvességtartalmának $\theta_{\text {hoagy }}$ ho nagy ugrása abban az esetben, ha a felszín alatti réteg homok. A $\theta_{\text {hoagy }}{ }^{\text {ho }}$ $0,10 \mathrm{~m}^{3} / \mathrm{m}^{3}$-ről $0,176 \mathrm{~m}^{3} / \mathrm{m}^{3}$ értékre változott, ami nem is meglepő ha a kezdeti $\theta$-értékekhez tartozó talajnedvesség-potenciál értékeket kiszámoljuk. Ha $\theta_{\text {hoagy }}=$ $0,1 \mathrm{~m}^{3} / \mathrm{m}^{3}$ és $\theta^{\text {ho }}=0,08 \mathrm{~m}^{3} / \mathrm{m}^{3}$, akkor a (7) egyenlet alapján $\Psi_{\text {hoagy }}=-537713,9$ és $\Psi^{\text {ho }}=-77,9 \mathrm{~m}$ a nedvességpotenciál, azaz a $0,08 \mathrm{~m}^{3} / \mathrm{m}^{3}$ nedvességtartalmú homokréteg sokkal nedvesebb, mint a felette levő $0,1 \mathrm{~m}^{3} / \mathrm{m}^{3}$ nedvességtartalmú 
homokos agyagréteg. A szimuláció első lépése után a $\theta_{\text {hoagy }}{ }^{\text {ho }}$ változásai kiegyensúlyozottak. A $\theta_{\text {hoagy }}$ ho minimális értéke $0,13 \mathrm{~m}^{3} / \mathrm{m}^{3}$ körül van.

A $\theta_{\text {hoagy }}{ }^{a g y}$ nem mutat ugrást a szimuláció első lépésében, mert a $\mathrm{Q}_{1}$ talajnedvesség-áram lefelé irányul és igen kicsi, mindössze $0,16 \cdot 10^{-11} \mathrm{~m} / \mathrm{s}$ értékủ. A tapasztalható ingadozások is kisebbek: A $\theta_{\text {hoagy }}{ }^{\text {agy }}$ maximális értéke $0,11 \mathrm{~m}^{3} / \mathrm{m}^{3}$, míg minimális értéke $0,07 \mathrm{~m}^{3} / \mathrm{m}^{3}$ körül van. Mindkét esetben a csapadék hatása egyértelmúen megjelenik.

Mivel $\theta_{\text {hoagy }}{ }^{\text {ho }}>\theta_{\text {hoagy }}{ }^{\text {agy }}$ a $P_{\text {hoagy }}$ ho nagyobb, mint a $\mathrm{P}_{\text {hoagy }}{ }^{\text {agy }}$. A párolgásbeli eltérések a déli órákban, vagyis a $\mathrm{P}_{\text {hoagy }}{ }^{\text {ho }} \mathrm{P}_{\text {hoagy }}{ }^{\text {agy }}$ különbségek elérhetik akár
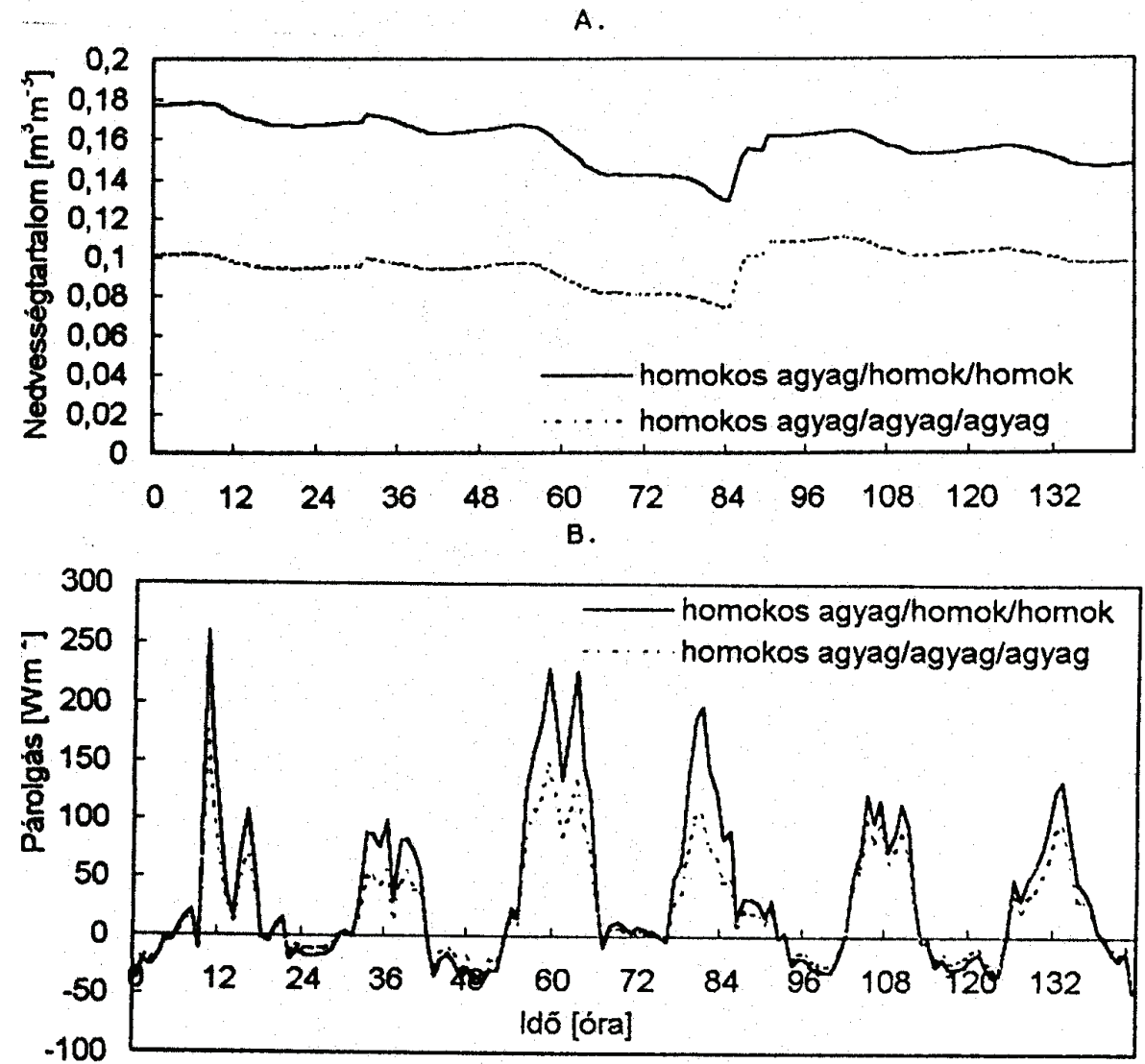

4. ábra

A felszíni homokos agyagréteg nedvességtartalmának (A), ill. párolgásának (B) időbeni változása az 1992. április 28. és május 3. közötti időszakban. A felszín alatti két réteg textúrája homok (telt vonal) és agyag (szaggatott vonal) 
a $100 \mathrm{~W} / \mathrm{m}^{2}-\mathrm{t}$ is (4B. ábra negyedik nap). A $\left[\left(\mathrm{P}_{\text {hoagy }}{ }^{\text {ho }}-\mathrm{P}_{\text {hoagy }}{ }_{\text {agy }}\right) / \mathrm{P}_{\text {hoagy }}{ }^{\text {agy }}\right] * 100$ relatív eltérések maximális értéke a déli órákban elérheti az $50 \%$-ot is (lásd a 4B. ábra második és negyedik napját).

\section{Az eredmények értékelése, megvitatása és következtetések}

A 2. és a 4. ábrák azt mutatják, hogy a felszíni nedvességtartalom és a párolgás érzékeny a felszíni és a felszín alatti fizikai talajféleség-változásokra. A felszíni és felszín alatti fizikai talajféleség-változásra modellezett érzékenység azonos nagyságrendű. Eredményeink alapján a párolgás esetében a felszíni fizikai talajféleség-eltérésekre a maximális relatív eltérés $70 \%$ is lehetett, míg a felszín alatti fizikai talajféleség-eltérésekre ugyanez $50 \%$ körülinek adódott. Ezek az értékek többszörösen meghaladják a párolgás 5-10\%-os mérési hibáját (SHARMA, 1983). Az eredmények természetesen szigorúan csak az alkalmazott kezdeti feltételekre és légköri határfeltételekre vonatkozóan érvényesek. A tapasztalt érzékenység megállapítása fontos lehet, mert a felszíni és a felszín alatti fizikai talajféleség adatok - föleg nagy területekre vonatkozóan - csupán pontatlanul ismertek.

Az eredményeink talajfizikai szempontból is tanúságosak. Megmutattuk, hogy a talajrétegek nedvességi állapotát - így a rétegek közötti nedvességáramok irányát és intenzitását is - nemcsak a talajrétegek nedvességtartalma, hanem a fizikai talajféleségükkel meghatározott vízgazdálkodási tulajdonságaik is meghatározzák. Eredményeink alapján egyértelmüen láttuk, hogy ugyanazon nedvességtartalom értékek mellett a finomabb szemcseösszetételü talaj (pl. agyag) szárazabb, azaz alacsonyabb (abszolút értékben nagyobb) talajnedvesség-potenciál értékkel rendelkezik, mint a durvább szemcseösszetételü talaj (pl. homok). Ez a megállapítás széleskörüen hasznosítható az agronómusok, geológusok, hidrológusok és a meteorológusok mindennapi gyakorlatában.

\section{Összefoglalás}

Vizsgálatunkban a csupasz talaj felszíni és felszín alatti fizikai talajféleségének, valamint a felszín nedvességi viszonyainak kapcsolatát elemeztük. Az elemzést a SURFMOD modellcsalád (ÁCS et al., 2000a) PMSURF modellváltozatával (ÁCS \& HANTEL, 1999) végeztük. Érzékenységi vizsgálataink során a braunschweigi szinoptikus meteorológiai állomáson mért légköri határfeltételeket és az irodalomból vett fizikai talajféleséggel meghatározott vízgazdálkodási tulajdonságokat (CLAPP \& HORNBERGER, 1978) használtuk. A modellfuttatásaink során a következő kérdésre kerestünk választ: mennyire érzékeny a felszín nedvességtartalma és párolgása a szinoptikus időjárási jelenségek 
karakterisztikus időskáláján (egynéhány nap) a felszíni és a felszín alatti fizikai talajféleség-változásokra? Eredményeink szerint rövid, egynéhány napos időskálán a felszíni nedvességtartalom és párolgás érzékeny a felszíni és a felszín alatti fizikai talajféleség változásokra. Az érzékenység azonos nagyságrendü. Párolgás esetében a felszíni fizikai talajféleség-eltérésekre a maximális relatív eltérés $70 \%$ körül adódott, míg a felszín alatti fizikai talajféleség-eltérésekre ugyanez 50 \% körül volt. Értékük többszörösen is meghaladja a párolgás 5$10 \%$-os mérési hibáját. A tapasztalt érzékenység ténye igen fontos, mivel a fizikai talajféleség adatok - főleg nagy területekre vonatkozóan - szerintünk bizonytalanok.

\section{Irodalom}

ÁCs F., 1998. A PROGSURF növénytakaró modell. In: II Erdő és Klíma Konferencia, (Sopron, 1997. június 4-6.) kiadványa. 158-162.

Ács, F. \& Hantel, M., 1998. The Land Surface Flux Model PROGSURF. Global Planet Change. 19. 19-34.

ÁCS, F. \& HANTEL, M., 1999: The Penman-Monteith concept based land-surface model PMSURF. Időjárás. 103. 19-36.

ÁCS, F., HANTEL, M. \& UNEGG, J., 2000a. The land-surface model family SURFMOD. Időjárás. 104. 21-41.

Ács, F., HANTEL, M. \& UnEGG, J., 2000b. Climate diagnostics with the BudapestVienna Land-Surface Model SURFMOD. In: Austrian Contributions to the Global Change Program. Vol. 3. Austrian Academy of Sciences, Vienna.

Clapp, R. B. \& Hornberger, G. M., 1978. Empirical equations for some soil hydraulic properties. Water Resour. Res. 14. 601-604.

CosBY, B. J. et al., 1984. A statistical exploration of the relationships of soil moisture characteristics to the physical properties of soils. Water Resour. Res. 20. 682-690.

IRANNEJAD, P. \& SHAO, Y., 1998. Description and validation of the atmosphere-landsurface interaction scheme (ALSIS) with HAPEX and Cabauw data. Global Planet Change. 19. 87-114.

MÉSZÁROS, R., L. et al., 2001. A troposzférikus ózon száraz ülepedésének mérése és modellezése. In: KÖM-MTA „Légszennyezés környezeti kárainak közgazdasági értékelése” Workshop (Budapest, 2001. április 5.) anyaga.

Minailovic, D. T. et al., 1992. A study of the sensitivity of land surface parameterizations to the inclusion of different fractional covers and soil textures. J. Appl. Meteor. 31. 1477-1487.

MonTEITH, J., 1965. Evaporation and environment. In Proc. $19^{\text {th }}$ Symp. Soc. Exp. Biol. 205-236. Cambridge University Press. Cambridge.

PITMAN, A .J., 1994. Assessing the sensitivity of a land-surface scheme to the parameter values using a single column model. J. Climate. 7. 1856-1869.

RicharDS, L. A., 1931. Capillary conductance of liquids through porous mediums. Physics. 1. 318-333. 
SHARMA, M. L., 1983. Estimating evapotranspiration. A. Water balance methods. Advances in Irrigation. 2. 237-242.

ShutTlEWORTH, W .J., 1988. Macrohydrology - The new challenge for process hydrology. J. Hydrol. 100. 31-56.

VÁRALlyAY GY. et al., 1980. Magyarországi talajok vízgazdálkodási tulajdonságainak kategóriarendszere és 1:100 000 méretarányú térképe. Agrokémia és Talajtan. 29. 77-112.

Érkezett: 2001. április 9. 